\title{
Passive immunity in foals born from mares vaccinated against Theileira equi and Streptococcus equi subspecies equi
}

\author{
Alice Corrêa Santos ${ }^{1}$ Carlos Eduardo Wayne Nogueira ${ }^{2}$ Leandro Quintana Nizoli $^{3}$ (D) \\ Vitória Müller ${ }^{1}$ Rafaela Pinto de Souza ${ }^{2} \mathbb{D}$ Ruth Patten ${ }^{2}$ Fábio Pereira Leivas Leite ${ }^{1 *}(\mathbb{D}$
}

${ }^{1}$ Centro de Desenvolvimento Tecnológico, Faculdade de Biotecnologia, Universidade Federal de Pelotas (UFPel), 96010-610, Pelotas, RS, Brasil. E-mail: fleivasleite@gmail.com. "Corresponding autor.

${ }^{2}$ Departamento de Clínicas Veterinária, Faculdade de Medicina Veterinária, Universidade Federal de Pelotas (UFPel), Pelotas, RS, Brasil

${ }^{3}$ Departamento de Veterinária Preventiva, Faculdade de Medicina Veterinária. Universidade Federal de Pelotas(UFPel), Pelotas, RS, Brasil

ABSTRACT: The aims of this study were: 1) determine total specific IgG and subisotypes in serum and colostrum of pregnant mares vaccinated against Theileria equi and Streptococcus equi subspecies equi; 2) determine total specific IgG and subisotypes in foals born from these mares. In mares, the highest total serum IgG value for T. equi was at 335 days of gestation declining 30 days postpartum, while for S. equi was at 328 days of gestation remaining high up to 30 days postpartum. Transfer of passive immunity against both antigens was observed with specific IgG values in colostrum and foals' serum proportional to mares'values. The most detected specific IgG subisotypes were IgG3/5 and IgG4/7 for both antigens. Foals born from mares immunized with T. equi kept maternal IgG values until 2 months of age, while those born from mares immunized with S. equi kept maternal IgG values until 3-4 months of age. These results suggest that foals should be vaccinated after this period. Key words: equine, vaccine, passive immunity, $\operatorname{Ig} G$ subisotypes.

Imunidade passiva em potros provenientes de éguas vacinadas contra Theileira equi e Streptococcus equi subspécie equi

RESUMO: Os objetivos deste estudo foram: 1) determinar IgG total especifica e seus subisotipos no soro e colostro de éguas vacinadas contra Theileria equi e Streptococcus equi subspécie equi; 2) determinar IgG total especifica e seus subisotipos em potros provenientes dessas éguas. Em éguas vacinadas contra T. equi, o maior nível sérico de IgG total específico ocorreu aos 335 dias de gestação, decaindo 30 dias pós parto, enquanto nas vacinadas contra $S$. equi, ocorreu aos 328 dias de gestação e manteve-se pelo mesmo periodo. A avaliação de IgG total especifica no colostro de éguas vacinadas demonstrou níveis de IgG proporcionais aos títulos do soro materno. Os isotipos de IgG mais detectados foram IgG3/5 e IgG4/7 para ambos antígenos avaliados. Potros provenientes de éguas vacinadas com antígeno de T. equi mantiveram os níveis de $\operatorname{IgG}$ especifica até dois meses de idade, enquanto potros provenientes de éguas vacinadas com antígeno de $S$. equi mantiveram por três a quatro meses, sugerindo que esse seja o periodo ideal para início do esquema vacinal em potros.

Palavras-chave: equinos, vacina, imunidade passiva, isotipos de $\operatorname{IgG}$.

\section{INTRODUCTION}

Theileria equi is a hemoparasite and one of the etiologic agents of equine piroplasmosis (KNOWLES Jr., 1996), an endemic disease in Brazil that causes severe hemolytic anemia (WISE et al., 2014). The bacteria Streptococcus equi subspecies equi is a microorganism responsible for causing strangles, a disease with high morbidity and one of the most common diseases of the equine upper respiratory tract (MORAES et al., 2009).

Immunocompetent horses produce IgG1 and IgG4/7 during acute $T$. equi infections. These antibody subisotypes are directly related to controlling infection (CUNHA et al., 2006), while IgG3/5 generally only appears during chronic infections (MEALEY et al., 2012). Antibody production in animals infected by $S$. equi is important for controlling infection and for establishing immunologic memory (FLOCK et al., 2004). The antibody subisotype $\operatorname{IgG} 4 / 7$ is the most frequently observed subisotype in the serum of $S$. equi infected animals, especially during the acute phase, followed by IgG1 (SHEORAN et al., 1997).

Understanding passive transfer is key to establishing vaccination protocols for foals (PERKINS \& WAGNER, 2015; BORDIN et al., 2014; WILSON et al., 2001). Foals respond inefficiently to most of the vaccines designed for use in adult, indicating a 
difficulty in developing protective vaccines in young horses. The development of a vaccine formulation for this age range requires the understanding of the interaction between passive immunity and the development of active immunity by the foal, which is still developing its immune system (PERKINS \& WAGNER, 2015).

Given the clinical and epidemiological importance of $T$. equi and $S$. equi, as well as the relevance of studying the immune response to these pathogens for vaccine development and control strategy improvement, the aims of the present study were to: 1) determine total specific IgG and subisotypes in serum and colostrum of pregnant mares vaccinated against $T$. equi and $S$. equi; 2) determine total specific vaccine antigens $\operatorname{IgG}$ and subisotypes in serum of foals born from vaccinated mares.

\section{MATERIALS AND METHODS}

\section{Animals}

Thirty two mare/foal pairs from the Centro de Ensino e Experimentação em Equinocultura da Palma (CEEEP), Universidade Federal de Pelotas/RS, Brazil. All mares were mixed breed, multiparous and aged between 10 and 15 years old. After pregnancy confirmation, gestations were monitored monthly by ultrasonography. Animals were kept on pasture (Lolium multiflorum) with water ad libitum during the entire experimental period. At the time of foaling, mares were brought into sanitized stalls and foalings were monitored and assisted when needed. Foals were closely monitored over the first 24 hours of life, received primary care and were then returned to the paddocks.

\section{Vaccines}

The recombinant protein EMA-2 was obtained using the protocol described by VIANNA et al. (2014). Briefly, a partial sequence of EMA-2 gene was amplified by PCR using as a template DNA extracted from the blood of an animal experimentally infected with the $T$. equi UFPEL E15 strain. The amplicon was cloned into pPICZ alphaB(Invitrogen ${ }^{\mathrm{TM}}$, USA), and the resulting plasmid was transformed into Pichia pastoris X33. A Mut ${ }^{+}$colony was selected to perform the expression of the recombinant protein, and the rEMA-2 protein was recognized by antibodies present in the serum of naturally infected horses. The vaccine was prepared by adding $200 \mu \mathrm{g}$ of the recombinant protein to aluminum hydroxide $10 \%$ (Al $(\mathrm{OH})_{3}$, Sigma-Aldrich ${ }^{\circledR}$, Darmstadt, Germany).

The $S$. equi antigen was obtained by using the protocol described by RIBAS et al. (2018), in which punch of retropharyngeal lymph nodes of naturally infected horses were performed and the $S$. equi isolate was confirmed through culture and PCR identification. For vaccine preparation, a strain of S. equi was cultured in Brain Heart Infusion (BHI) (Sigma-Aldrich) with $1 \%$ peptone added for 18 hours at $37^{\circ} \mathrm{C}$. The culture was centrifuged at $2150 \times \mathrm{g}$ in the A-4-44 rotor of a 5804 centrifuge (Eppendorf ${ }^{\circledR}$ from Brazil, São Paulo, Brazil) and the pellet was suspended in sterile saline. Titration was then performed through serial dilution and seeding in BHI agar base. In order to prepare the vaccine, a bacterial suspension containing $2.5 \times 10^{8} \mathrm{CFU} / \mathrm{ml}$ was inactivated in $37 \%$ formalin (1:5.000) (Labsynth ${ }^{\circledR}$, São Paulo, Brazil) and adsorbed in $10 \% \mathrm{Al}(\mathrm{OH})_{3}$ adjuvant (Sigma-Aldrich $\left.{ }^{\circledR}\right)$.

Mares were assigned randomly to three different groups: 1) Vaccinated Group - T. equi antigen $(\mathrm{n}=15) ; 2)$ Vaccinated Group - S. equi antigen (n $=12)$; 3) Control Group - inoculated with $\mathrm{Al}(\mathrm{OH})_{3}$ and PBS $(\mathrm{n}=5)$. The vaccination protocol started at 300 days of gestation, with a booster vaccination at 21 days after the first dose. Clinical parameters such as heart rate, respiratory rate, capillary perfusion time, mucosal staining and rectal temperature of the mares were evaluated weekly. Blood was collected by venipuncture of the external jugular vein using 25 x 8 gauge needles and tubes without anticoagulant (BD Vacutainer ${ }^{\circledR}$, New Jersey, USA) weekly from day 300 (first vaccination) until foaling, at the time of foaling and then at 7 and 30 days postpartum in order to obtain serum. Foals were divided into: 1) Foals born from mares included in the Vaccinated Group - T. equi antigen $(\mathrm{n}=15)$; 2) Foals born from mares included in the Vaccinated Group - S. equi antigen (n $=12)$; 3 ) Foals born from Control mares - vaccinated with $\mathrm{Al}(\mathrm{OH})_{3}$ and PBS $(\mathrm{n}=5)$. Blood was collected from foals by venipuncture of the external jugular vein using $25 \times 8$-gauge needles and tubes without anticoagulant (BD Vacutainer ${ }^{\circledR}$, New Jersey, USA). Samples were collected at the time of birth, at 12 hours and at 7, 15, 30 and 60 days of life. Blood samples were centrifuged at $1008 \mathrm{X} \mathrm{g}$ in analogical clinical centrifuge (Centrilab ${ }^{\circledR}$ 80-2B-15ml, São Paulo, Brazil) and serum was stored in $1.5 \mathrm{ml}$ microtubes (Eppendorf ${ }^{\circledR}$, São Paulo, Brazil) at $-20^{\circ} \mathrm{C}$ until further analysis. Mares had $2 \mathrm{ml}$ of colostrum collected manually immediately after parturition. Colostrum was stored in $1.5 \mathrm{ml}$ microtubes (Eppendorf ${ }^{\circledR}$, São Paulo, Brazil) at $-20{ }^{\circ} \mathrm{C}$ until further analysis.

Dynamics of serum total specific IgG and subisotypes Equine serum and colostrum samples were analyzed by indirect enzyme-linked immunosorbent 
assay (ELISA) to determine anti-S. equi/ anti-T. equi total IgG. In the samples tested for the T. equi antigen, the protocol described by VIANNA et al. (2014) was used with rEMA-2. Polystyrene plates containing 96-wells (Nunc-Immuno ${ }^{\mathrm{TM}}$, VWR ${ }^{\mathrm{TM}}$, Barcelona, Spain) were sensitized with $200 \mathrm{ng} / \mathrm{well}$ of rEMA-2 during 18 hours at $4{ }^{\circ} \mathrm{C}$. After blocking with $0.5 \%$ milk powder, the sera tested were added in 1:100 dilution and incubated for 60 minutes at 37 ${ }^{\circ} \mathrm{C}$. The anti-equine conjugated serum was added in 1:6.000 dilution and incubated for 90 minutes at $37{ }^{\circ} \mathrm{C}$. Development was accomplished by adding chromogen/substrate citrate/phosphate buffer (TPS), keeping the plates in the dark for 15 minutes. The reaction was interrupted by adding $\mathrm{H}_{2} \mathrm{SO}_{4} \quad 1 \mathrm{~N}$ solution. Absorbance was measured on a microplate reader (TP-READER - Thermo Plate $\AA$, Brazil) using a $492 \mathrm{~nm}$ wavelength.

For the $S$. equi antigen, serum and colostrum from mares and serum from foals were analyzed individually by ELISA using the protocol described by RIBAS et al. (2018). Polystyrene plates containing 96-wells (Nunc-Immuno ${ }^{\mathrm{TM}}$, VWR ${ }^{\mathrm{TM}}$, Barcelona, Spain) were sensitized with $10^{6} \mathrm{CFU} /$ $\mathrm{ml}$ of $S$. equi suspended in carbonate-bicarbonate buffer for 90 minutes at $37{ }^{\circ} \mathrm{C}$. After blocking with $0.5 \%$ milk powder, the sera tested were added in 1:100 dilution and incubated for 60 minutes at 37 ${ }^{\circ} \mathrm{C}$. Rabbit anti-horse IgG peroxidase conjugated (Sigma-Aldrich $^{\circledR}$, Darmstadt, Germany) was added in 1:6.000 dilution and incubated for 90 minutes at $37{ }^{\circ} \mathrm{C}$. Development was accomplished by adding chromogen/substrate citrate/phosphate buffer (TPS) and keeping the plates in the dark for 15 minutes. The reaction was interrupted by adding $\mathrm{H}_{2} \mathrm{SO}_{4} 1 \mathrm{~N}$ solution. Absorbance was measured on a microplate reader (TP-READER - Thermo Plate ${ }^{\circledR}$, Brazil) using a $492 \mathrm{~nm}$ wavelength.

The positive control for rEMA-2 was a sample of serum from a horse naturally infected with T. equi, confirmed by immunofluorescence and PCR. The positive control for $S$. equi was a sample of serum from a horse naturally infected with $S$. equi, confirmed through culture and microbial identification. As a negative control, in both tests, a newborn foal serum collected before the first suckling was used at 1:100 dilution. All samples and controls were tested in duplicate.

Immunoglobulin $G$ specific subisotypes were determined by indirect ELISA assay. The following subisotypes were tested: IgG1, IgG3/5 and IgG4/7 (Sigma-Aldrich ${ }^{\circledR}$, Darmstadt, Germany). A pool of serum from all vaccinated mares (samples from 300 to 328 days of gestation), pool of colostrum from all mares, and a pool of serum from all foals born from vaccinated mares (samples from 12 hours of life, 7 days and 1 month of age) were used in order to determine IgG subisotypes.

In the isotyping of antibodies to T. equi antigen, 96-well polystyrene plates (Nunc-Immuno ${ }^{\text {TM }}$, VWR $^{\mathrm{TM}}$, Barcelona, Spain) were sensitized with 200ng/well of rEMA-2 during 18 hours at $4{ }^{\circ} \mathrm{C}$. After washes with PBS-T, blocking with milk powder was performed and sera to be tested were added in 1:100 dilution and incubated for 60 minutes at 37 ${ }^{\circ} \mathrm{C}$. Subisotypes were tested in 1:1000 dilution and incubated for 30 minutes at $37^{\circ} \mathrm{C}$. After washings, conjugated sera were added: anti-goat for $\mathrm{IgG} 3 / 5$ and anti-mouse for IgG1 and $\mathrm{IgG} 4 / 7$ in 1: 4000 dilution and incubated for 60 minutes at $37^{\circ} \mathrm{C}$. Development was accomplished by adding chromogen/substrate citrate/phosphate buffer (TPS) and keeping the plate in the dark for 15 minutes. The reaction was interrupted by the addition of $\mathrm{H}_{2} \mathrm{SO}_{4} 1 \mathrm{~N}$. Absorbance was measured on a microplate reader (TP-READER - Thermo Plate ${ }^{\circledR}$, Brazil) using $492 \mathrm{~nm}$ wavelength.

A similar protocol was used to determine $S$. equi antigen-reactive IgG subisotypes, differing only in the plate sensitization step. A 96-well polystyrene plate (Nunc-Immuno ${ }^{\mathrm{TM}}$, VWR ${ }^{\mathrm{TM}}$, Barcelona, Spain) was sensitized with $10^{6} \mathrm{CFU} / \mathrm{ml}$ of $S$. equi carbonate-bicarbonate buffer for 90 minutes at $37^{\circ} \mathrm{C}$. Subsequent steps were the same as those described for the T. equi antigen.

\section{Statistical analysis}

The Shapiro-Wilk test was used to verify data normality. Data that did not present normal distribution were transformed into base 10 logarithm. Analysis of variance (ANOVA), and post-hoc comparisons were carried out by the Tukey test. Significance was set at $\mathrm{P}<0.05$. The commercial software Statistix $10.0^{\circledR}$ (Statistix, Tallahassee, FL, USA) was used for data analysis and graphs were developed using the commercial software GraphPad Prism 5.0 (GraphPad Software Inc., San Diego, CA, USA).

\section{RESULTS}

No adverse effects caused by vaccinations were observed in the animals included in this study, nor were any cases or outbreaks of these diseases diagnosed during the study period. All vaccinated mares responded to the vaccine with an increase of total specific $\operatorname{IgG}$, whereas no increase $\operatorname{IgG}$ was observed in control animals, with levels remaining 
constant for the whole experimental period. Mares vaccinated against $T$. equi and $S$. equi responded to vaccine antigens, differing statistically from the control group starting from the vaccine boost at 321 days of gestation, $(\mathrm{P}<0.05)$ (Figure 1).

The dynamics of total specific IgG differed among groups. In the $T$. equi vaccinated group, the highest values were observed at 335 days, 14 days after the booster vaccination. However, in those vaccinated against $S$. equi, for the higher ELISA values was observed at 328 days, 7 days after the booster vaccination. In contrast, no changes in specific $\operatorname{IgG}$ for $T$. equi and $S$. equi were observed in the control group. Total specific IgG values differed in the colostrum collected from mares from both the T. equi vaccinated group and the $S$. equi vaccinated group, when compared to the mares from the control group (Table 1).
In regard to the $\operatorname{IgG}$ subisotype profile, IgG3/5 was the most recognized antibody subisotype in mares vaccinated against $T$. equi and $S$. equi at 300 and 328 days of gestation, followed by $\operatorname{IgG} 4 / 7$. An increase in $\operatorname{IgG}$ subisotypes was observed in mares vaccinated with $T$. equi and $S$. equi antigens after booster vaccination (328 days). The most recognized $\mathrm{IgG}$ subisotype in the colostrum of the $T$. equi vaccinated group was the IgG3/5, followed by $\operatorname{IgG} 4 / 7$ and IgG1. In mares from the $S$. equi vaccinated group, there was a significant increase in $\operatorname{IgG} 3 / 5$ and IgG4/7 after vaccination, and these subisotypes were also identified in the colostrum, while IgG1 was not detected (Figure 2).

At the time of birth (0 hours), no specific T. equi and S. equi IgG were identified in the serum of the foals. However, after colostrum ingestion (12 hours), all foals presented specific T. equi and S. equi
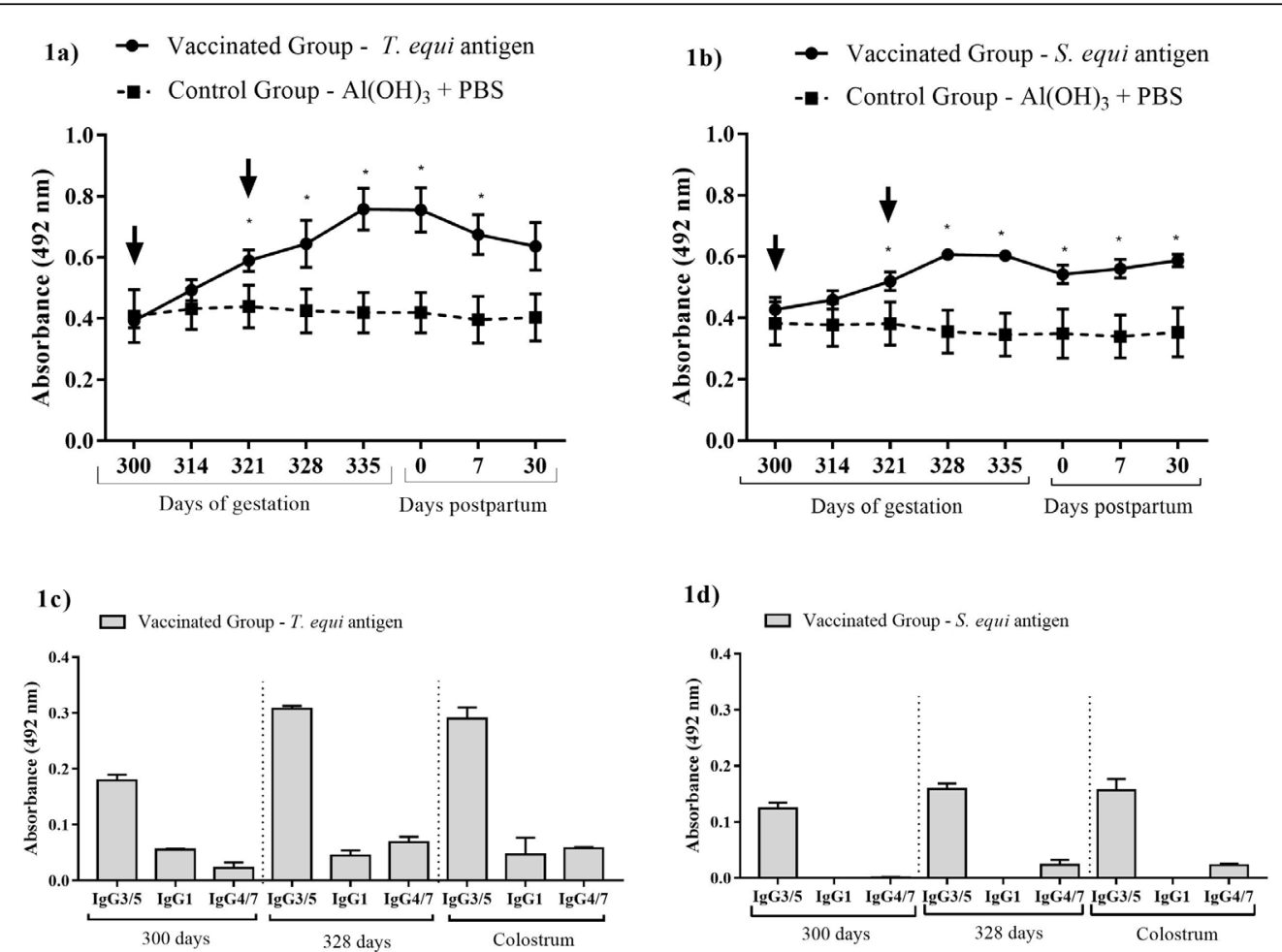

Figure 1 - Serum dynamics of total specific IgG of vaccinated and control mares and IgG subisotypes in vaccinated mares. The data represents the mean $( \pm \mathrm{SE})$ absorbance. 1a) Total specific IgG in Theileria equi Vaccinated and Control Group. 1b) Total specific IgG in Streptococcus equi Vaccinated and Control Group. 1c) IgG subisotypes in the Theileria equi Vaccinated Group 1d) IgG subisotypes in the Streptococcus equi Vaccinated Group. Vaccinations $(\downarrow)$ were performed at 300 and 321 days of gestation. Asterisks $\left(^{*}\right)$ indicate statistical difference among groups $(\mathrm{P}<0.05)$. 
Table 1 - Total specific IgG in colostrum of mares vaccinated against Theileria equi, mares vaccinated against Streptococcus equi and in the colostrum of control mares.

\begin{tabular}{lccc}
\hline & Vaccinated group & Control group & \\
\hline T. equi & $0.83 \pm 0.28 \mathrm{a}$ & $0.39 \pm 0.11 \mathrm{~b}$ & $\mathrm{P}=0.0021$ \\
S. equi & $0.61 \pm 0.2 \mathrm{a}$ & $0.50 \pm 0.02 \mathrm{~b}$ & $\mathrm{P}=0.02$ \\
\hline
\end{tabular}

Footnote: Results are described as Mean \pm SE of absorbance $(492 \mathrm{~nm})$. Different letters indicate statistical difference among groups $(\mathrm{P}<0.05)$.

IgG levels in serum. Foals born from mares vaccinated against T. equi had IgG OD492nm values of about 3.5 times higher than those born from control mares $(\mathrm{P}>$ 0.05). Foals born from mares vaccinated against $S$. equi had specific IgG OD492nm values of about two times higher than those born from control mares ( $\mathrm{P}$ $>0.05)$. Total specific IgG levels were distinct for $T$. equi and $S$. equi vaccines (Figure 2).

The observed specific IgG subisotypes in colostrum were very similar to those observed in the serum of foals at 12 hours after birth, and both were similar to those identified in the maternal serum at 328 days of gestation. This observation suggests that these subisotypes were transferred via passive immunity.

The IgG3/5 subisotype was predominant in foals born from vaccinated mares. Foals born from mares vaccinated against $T$. equi showed levels of the $\mathrm{IgG} 3 / 5$, IgG1 and IgG4/7 subisotypes. It is worth noting that the level of $\mathrm{IgG} 3 / 5$ decreased between 7 and 30 days postpartum, while the other subisotypes did not. Foals born from mares vaccinated against $S$. equi showed levels of $\mathrm{IgG} 3 / 5$ and $\mathrm{IgG} 4 / 7$ and those subisotypes followed the same trend observed for the T. equi antigen. 2a) $\rightarrow$ Foals born from Vaccinated Group - T. equi antigen

-匹. Foals born from Control Group - $\mathrm{Al}(\mathrm{OH})_{3}+\mathrm{PBS}$

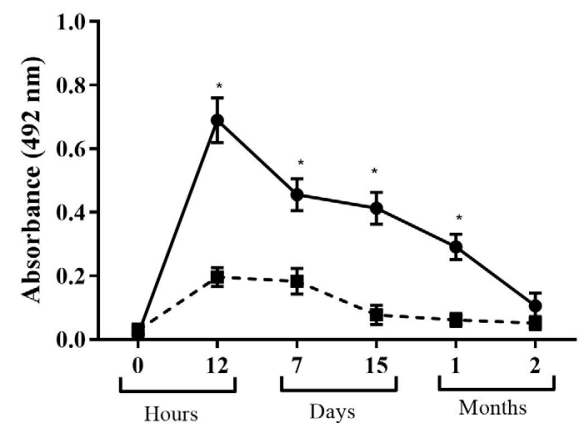

2c)

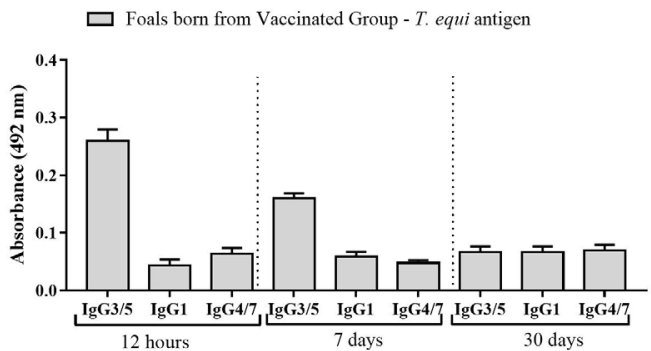

2b)
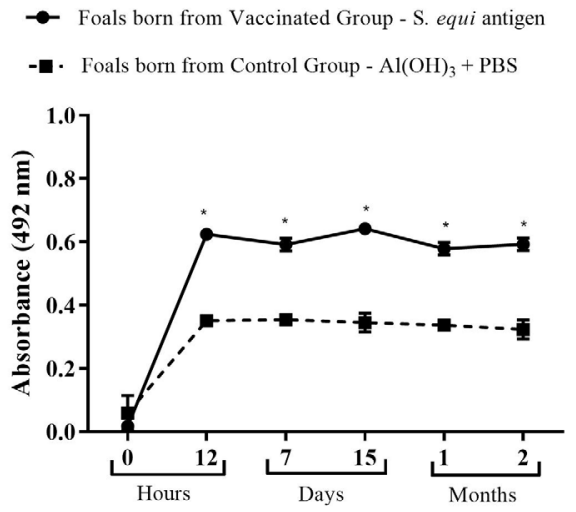

2d)

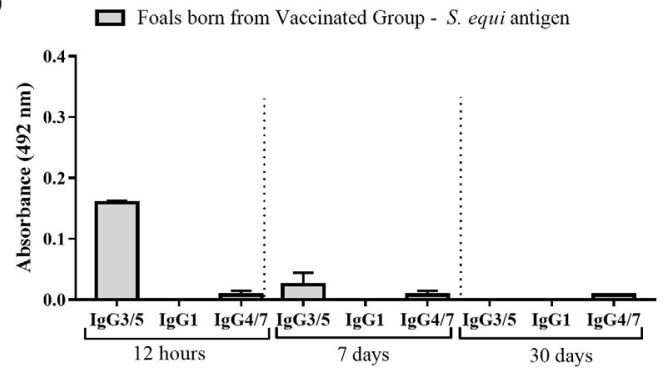

Figure 2 - Serum dynamics of total specific IgG in foals born from vaccinated and control mares and serum IgG subisotypes in vaccinated foals. The data represents the mean $( \pm \mathrm{SE})$ absorbance. $2 \mathrm{a})$ Total specific IgG in foals born from Theileria equi vaccinated mares and foals born from control mares. 2b) Total specific IgG in foals born from Streptococcus equi vaccinated mares and foals born from control mares. 2c) IgG subisotypes in foals born from Theileria equi vaccinated mares. 2d) IgG subisotypes in foals born from Streptococcus equi vaccinated mares. Asterisks (*) indicate statistical difference among vaccinated and control groups $(\mathrm{P}<0.05)$ 


\section{DISCUSSION}

In the first months of life the adaptive immune system of the foal is immature, and their innate immunity differs from immune mechanisms in the adult horse (PERKINGS \& WAGNER, 2015). Therefore, protection against pathogens is provided soon after birth through the ingestion of immunoglobulin present in the colostrum.

At 21 days after the first vaccination, Theileria equi vaccinated mares presented statistically higher total specific IgG levels compared to the control group. However, at 30 days post parturition (which is about 65 days after the first vaccination), no statistical difference between vaccinated and control groups was found. These results corroborate with those described by VIANNA et al. (2019), which demonstrated maintenance of anti-rEMA-2 vaccine antibodies until approximately 60 days after the first vaccination in adult horses. Mares vaccinated with the $S$. equi antigen showed statistically higher total specific IgG levels than those from the control group even at 30 days postpartum. Using a similar vaccine for S. equi, RIBAS et al. (2018) observed a total specific IgG presence in vaccinated horses for up to 100 days.

Foals born from T. equi vaccinated mares had a significant increase in specific $\operatorname{IgG}$ after colostrum absorption, approximately 43-times higher than initial OD492nm values, while foals born from control mares had an increase of only 6.8 times the initial OD492nm values. At 7 days after birth, the IgG levels started to decrease in both groups, reaching the lowest level at 2 months of age. This observation corroborates with those found by KUMAR et al. (2008), where they reported that total specific IgG levels did not differ statistically from control values in foals at the age of two months. Further, a study performed by our group (VIANNA et al., 2019), suggests the administration of a third dose around 60 days after the first vaccination in horses using rEMA-2. Specific IgG ELISA results demonstrated that foals born from mares vaccinated against $S$. equi had an increase of 34.3 times de initial optical density after colostrum absorption, whereas foals born from control mares had an increase of only 5.9 times the initial optical density. Although optical density does not directly correlate with IgG levels, these results suggest an increase in antibody levels in foals born from vaccinated mares. What is interesting is that even with a statistical difference in optical density between these groups over the first two months, it remained at the same levels, differing from results found in foals born from mares vaccinated against T. equi. In 2018, RIBAS et al. reported that maternal antibodies against $S$. equi remain circulating in foals until 3 months of life, which suggests that immunization schedule should start at this age, when maternal antibodies decay. This data corroborates with the results found in the present study. A similar colostrum immunoglobulin duration was observed by CAUCHARD et al. (2004), evaluating a vaccine against Rhodococcus equi. Studies of IgG subisotypes in the transfer of passive immunity remain scarce, especially in mares vaccinated against $T$. equi and $S$. equi. The predominance of $\mathrm{IgG} 3 / 5$ in the vaccine response may suggest that the vaccine used induces protection (WILSON et al., 2001). In animals naturally infected by $T$. equi, IgG3/5 predominates, suggesting that this is the main subisotype involved in parasite control (MEALEY et al., 2012). In convalescent animals which were previously infected by $S$. equi, $\mathrm{IgG} 4 / 7$ and $\mathrm{IgG} 3 / 5$ were the main subisotypes identified (SHEORAN et al., 1997), similar to the results observed in our study. The isotyping results resemble those reported by MEALEY et al. (2012) and SHEORAN et al. (1997) in naturally infected animals, suggesting that the vaccine antigens mimic the natural immune response.

As previously described by PERKINS \& WAGNER (2015), equine colostrum is directly related to maternal serum immunoglobulin, with IgG4/7 predominating, followed by $\mathrm{IgG} 1$ and $\operatorname{IgG} 3 / 5$. The immunoglobulin $\mathrm{IgG} 4 / 7$ plays an essential role in protection against bacterial and viral infections (LOPEZ et al., 2002). Both IgG1 and $\mathrm{IgG} 3 / 5$ are substantially raised in colostrum and mediate immune functions in protecting the newborn PERKINS \& WAGNER (2015). Mare vaccination at the end of gestation is essential in order to concentrate neutralizing antibodies, which can protect the foal during the first months of age (LOPEZ et al., 2002).

The subisotype $\operatorname{IgG} 3 / 5$ predominated in foals born from $T$. equi vaccinated mares, followed by IgG4/7 and IgG1, with detectable levels up to 30 days of life. In foals born from $S$. equi vaccinated mares, the subisotypes $\operatorname{IgG} 3 / 5$ and $\operatorname{IgG} 4 / 7$ were detected at significant levels up to 7 days of life. This observation is quite important considering that IgG3 is the most important equine IgG subclass and can trigger a strong respiratory burst via the Fc receptor. Additionally, the subisotypes IgG1, IgG4-7 and IgG3-5 observed in vaccinated mares can promote Fc-receptor interactions and complement activation (LEWIS et al., 2008).

In the present study, antibodies against $T$. equi and $S$. equi antigens were detected in the first 
serum samples of vaccinated and control mares (D0), which may suggest previous contact with these pathogens. Some initial value was expected, possibly due to previous contact with the pathogens, given that $T$. equi is endemic in the study region and as such may persist in the herd by asymptomatic carriers (WISE et al., 2014). The same could be attributed to $S$. equi, since strangles is also prevalent in the Rio Grande do Sul state, where the study was performed (MORAES et al., 2009). Given the age of the mares enrolled in this study and the prevalence of strangles in this region, contact with the agent is likely to have occurred at least once over the course of their lifetime, which may explain the serological findings. However, one may consider a characteristic background of non-competitive serological reactions, especially identified in equine serum (CRAIGO et al., 2012). Nevertheless, in comparison to the groups vaccinated against $T$. equi and $S$. equi, the total specific IgG levels of control animals remained linear during the study period, indicating that there were no outbreaks during the experimental period.

Vaccination against $T$. equi and $S$. equi has not yet reached a consensus across equine breeders and veterinarians. The fact that there are no commercial vaccines available against $T$. equi suggests that a certain level of doubt concerning the benefits of the vaccine could exist (ROTSCHILD, 2013). Although there are $S$. equi vaccines available, their efficacy is often questioned (ARIAS GUTIÉRREZ, 2013). Commercial and experimental vaccines still require further study, especially regarding antigenic variability and immunogenicity (ARIAS GUTIÉRREZ, 2013), which may have contributed to their not being widely adopted in vaccine protocols. In practice, the use of experimental vaccines increases after the occurrence of outbreaks. Although antibody values do not necessarily indicate protection, clinical observations on properties that regularly vaccinate do indicate a decrease in the number of cases, suggesting a relationship with herd immunity.

\section{CONCLUSION}

Mares vaccinated at 300 days of gestation had higher total specific vaccinal antibodies for both vaccines, with a similar profile of total specific IgG and subisotypes transferred to their foals. Based on the present study, one can suggest that the age of two months could be the ideal time to start the T. equi immunization in foals, if a vaccine were to be available. On the other hand, considering the present and previous studies, the age of 3-4 months can be suggested as the ideal time to start $S$. equi immunization in foals.

\section{ACKNOWLEDGEMENTS}

We would thank to Coordenação de Aperfeiçoamento de Pessoal de Nível Superior (CAPES) - Brazil for ACS, RPS, and RP scholarships - Finance Code 001 and Conselho Nacional de Desenvolvimento Científico e Tecnológico (CNPq) for VM, CEWN and FPLL scholarships.

\section{DECLARATION OF CONFLICT OF INTEREST}

We have no conflict of interest to declare.

\section{AUTHORS' CONTRIBUTIONS}

ACS contributed to experiment design, experiments and writing the manuscript. CEWN contributed to experiment design, analyses of results and manuscript revision, LQN contributed to experiment design, VM contributed to the experiments and manuscript revision, RPS contributed to the experiments and manuscript revision, RP contributed to the experiment and manuscript revision, and FPLL contributed to designed the study, analyses of results and manuscript revision.

\section{BIOETHICS AND BIOSSECURITY COMMITTEE APPROVAL}

All procedures carried out in this study were approved by the Ethical Committee for Animal Experimentation at the Universidade Federal de Pelotas (CEEA-UFPel), under protocol 7896.

\section{REFERENCES}

ARIAS GUTIÉRREZ M. P. Strangles: the most prevalent infectious respiratory disease in horses worldwide. CES Medicina Veterinaria y Zootecnia. v.8, n.1, p.143-159. Available from: $<$ https://revistas.ces.edu.co/index.php/mvz/article/view/2840>. Accessed: Mar. 02, 2021. doi: 10.21615/2840.

BORDIN, A. I. et al. Imunogenicity of an electron beam inactivated Rhodococcus equi vaccine in neonatal foals. PLoS ONE. v.9, n.8, p.1-11. Available from: <https://www.ncbi.nlm.nih.gov/pmc/ articles/PMC4143214/pdf/pone.0105367.pdf>. Accessed: Apr. 28, 2021. doi: 10.1371/journal.pone.0105367.

CAUCHARD, J. et al. Foal IgG and opsonizing anti-Rhodococcus equi antibodies after immunization of pregnant mares with a protective VapA candidate vaccine. Veterinary Microbiology. v.104, n.1-2, p.73-81, 2004. Available from: $<$ https://pubmed.ncbi. nlm.nih.gov/15530741/>. Accessed: Mar. 04, 2021. doi: 10.1016/j. vetmic.2004.09.006.

CRAIGO, J. K. et al. Development of a high throughput, semiautomated, infectious center cell-based ELISA for Equine Infectious Anemia Virus. Journal of Virological Methods. v.185, n.2, p.221-227, 2012. Available from: <https://www.ncbi.nlm.nih. gov/pmc/articles/PMC3474874/>. Accessed: Mar. 03, 2021. doi: 10.1016/j.jviromet.2012.07.007. 
CUNHA, C. W. Development of specific immunoglobulin Ga (IgGa) and IgGb antibodies correlates with control of parasitemia in Babesia equi infection. Clinical and Vaccine Immunology. v.13, p.297-300, 2006. Available from: <https://cvi.asm.org/ content/13/2/297>. Accessed: Mar. 04, 2021. doi: 10.1128/ CVI.13.2.297-300.2006.

FLOCK, M. et al. L. Recombinant Streptococcus equi proteins protect mice in challenge experiments and induce imune response in horses. Infection and Immunity. v.72, n. 6, p.3228-3236, 2004. Available from: <https://iai.asm.org/content/72/6/3228>. Accessed: Mar. 03, 2021. doi: 10.1128/IAI.72.6.3228-3236.2004.

KNOWLES Jr, D. Equine babesiosis (piroplasmosis): A problem in the international movement of horses. British Veterinary Journal, v.152, n.2, p.123-126, 1996. Available from: <https://www. sciencedirect.com/science/article/abs/pii/S0007193596800662>. Accessed: Mar. 04, 2021. doi: 10.1016/S0007-1935(96)80066-2.

KUMAR, S. et al. Passive transfer of Theileria equi antibodies to neonate foals of immune tolerant mares. Veterinary Parasitology. v.151, n.1, p.80-85, 2008. Available from: $<$ https://europepmc.org/ article/med/18022185>. Accessed: Mar. 04, 2021. doi: 10.1016/j. vetpar.2007.10.001

LEWIS, M. J. et al. The different effector function capabilities of the seven equine IgG subclasses have implications for vaccine strategies. Molecular Immunology. v.45, n.3, p.818-827, 2008. Available from: <https:/www.sciencedirect.com/science/ article/pii/S0161589007004208>. Accessed: Mar. 03, 2021. doi: 10.1016/j.molimm.2007.06.158

LOPEZ, A. M. et al. Identification of pulmonary T-lymphocyte and serum antibody isotype responses associated with protection against Rhodococcus equi. Clinical and Diagnostic Laboratory Immunology. v.9, n.6, p.1270-1276, 2002. Available from: $<$ https://cvi.asm.org/content/9/6/1270>. Accessed: Mar. 04, 2021. doi: 10.1128/CDLI.9.6.1270-1276.2002

MEALEY, R. H. et al. Protective effects of passively transferred merozoite-specific antibodies against Theileria equi in horses with severe combined immunodeficiency. Clinical and Vaccine Immunology. v.19, n.1, p.100-104, 2012. Available from: $<$ https://cvi.asm.org/content/19/1/100>. Accessed: Mar 04, 2021. doi: $10.1128 /$ CVI.05301-11.

MORAES, C. M. et al. Adenite equina: sua etiologia, diagnóstico e controle. Ciência Rural. v.39, n.6, p.1944-1952, 2009 Available from: $<$ https://www.scielo.br/scielo.php?pid=S0103$84782009000600050 \&$ script $=$ sci abstract\&tlng $=\mathrm{pt}>$. Accessed Mar. 03, 2021. doi: 10.1590/S0103-84782009000600050.
PERKINS, G.A., WAGNER, B. The development of equine immunity: Current knowledge on immunology in the young horse. Equine Veterinary Journal. v.47, p.267-274, 2015. Available from: $\quad<$ https://beva.onlinelibrary.wiley.com/doi/10.1111/ evj.12387>. Accessed: Mar. 05, 2021. doi: 10.1111/evj.12387.

RIBAS, L. M. et al. "Cell ELISA" como ferramenta auxiliar no controle da adenite equina. Arquivo Brasileiro de Medicina Veterinária e Zootecnia. v.70, n.1, p.20-28, 2018. Available from: <https://www.scielo.br/scielo.php?pid=S010209352018000100020\&script $=$ sci abstract $>$. Accessed: Mar. 02, 2021. doi: $10.1590 / 1678-4162-9637$

ROTSCHILD, C. M. Equine Piroplasmosis. Journal of Equine Veterinary Science. v.33, n.7, p.497-508, 2013. Available from: $<$ https:// www.sciencedirect.com/science/article/abs/pii/S0737080613003079>. Acessed: Mar. 04, 2021. doi: 10.1016/j.jevs.2013.03.189.

SHEORAN, A. S. et al. Serum and mucosal antibody isotype responses to M-like protein (SeM) of Streptococcus equi in convalescent and vaccinated horses. Veterinary Immunology and Immunopathology. v.59, n.3-4, p.239-251, 1997. Available from: <https://www. sciencedirect.com/science/article/abs/pii/S0165242797000743>. Accessed: Mar. 04, 2021. doi: 10.1016/S0165-2427(97)00074-3.

VIANNA, A. M. et al. Antigenicity assessment of the Theileria equi merozoite antigen (EMA-2) expressed in Pichia pastoris in mice and horses. Experimental Parasitology. v.206, p.1-5, 2019. Available from: <https:/www.sciencedirect.com/science/article/ abs/pii/S0014489419301110>. Accessed: Mar. 03, 2021. doi: 10.1016/j.exppara.2019.107757.

VIANNA, A. M. et al. Expressão heteróloga da EMA-2 (Equi Merozoite Antigen) de Theileria Equi em Pichia Pastoris com potencial utilização em imunobiológicos. Ciência Rural. v.44, n.10, p.1830-1836, 2014. Available from: <https://www.scielo.br/ scielo.php?script $=$ sci arttext\&pid $=\mathrm{S} 0103-84782014001001830>$. Accessed: Mar. 04, 2021. doi: 10.1590/0103-8478cr20131003.

WILSON, W. D. Passive transfer of maternal immunoglobulin isotype antibodies against tetanus and influenza and their effect on the response of foals to vaccination. Equine Veterinary Journal. v.33, n.7, p.644-650, 2001. Available from: $<$ https://beva. onlinelibrary.wiley.com/doi/abs/10.2746/042516401776249435>. Accessed: Mar. 05, 2021. doi: 10.2746/042516401776249435.

WISE, L. N. et al. Equine Piroplasmosis. Veterinary Clinics of North America: Equine Practice, v.30, n.3, p.677-693, 2014. Available from: <https://www.sciencedirect.com/science/article/ abs/pii/S0749073914000662>. Accessed: Mar. 03, 2021. doi: 10.1016/j.cveq.2014.08.008. 